\title{
Free Metal Restoration of a Dilapidated Maxillary Central Incisor: A Clinical Report
}

\author{
Mohamed Chebil ${ }^{1}$, Zied Fedaoui ${ }^{2}$, Mounir Cherif $^{3}$ \\ ${ }^{1}$ Assistant Professor, Department of Fixed Prosthodontics, Dental Clinic of Monastir, Tunisia \\ ${ }^{2}$ DDS, Department of Fixed Prosthodontics, Dental Clinic of Monastir, Tunisia \\ ${ }^{3}$ Professor Head of Department; Department of Fixed Prosthodontics, Dental Clinic of Monastir, Tunisia
}

\begin{abstract}
The restoration of the dilapidated maxillary central incisoris a frequenttask in our practice. The systematic use of metalceramic crowns and in lay cores should stop. Metal-ceramic restoration were the standard prostheses for bothesthetic and mechanical requirements. But they have many limits and disadvantages in relation with metalalloy. Currently, all-ceramic crowns and AdhesiveCorono-Radicular Reconstructions shouldbeconsidered as the optimal treatment.
\end{abstract}

Keywords : dilapidated maxillary incisor, free-metal restoration, adhesive corono-radicular reconstruction, all-ceramic restoration.

\section{Introduction}

Since the discovery of feldsparceramicsat the beginning of the last century, metal-ceramic systems have been considered as restorations of choice for posterior teeth as well as for anterior ones [1] .This type of prosthesisis composed of a metal alloy framework covered with a cosmetic ceramic [2]. Numerous studies have been conducted to study the reliability of this system and have all demonstrated that the major advantage of these restoration is their long-term durability thanks to their mechanical resistance. However, these same studies have revealed that the optical properties of metal-ceramic crowns are questionable because the metallic framework blocks the passage of light[3].

This gives the tooth a rather opaque appearance that does not conform to the natural appearance.

This effect is further accentuated by the use of metallic post and core and, to a lesser degree, with the use of a metallic post and composite core combination.

Other disadvantages are found for the metal alloys used: nickel allergy in some cases, problems of electrogalvanism (corrosion) and artifactsat the level of scanners and Magnetic Resonance Imaging [4].All-ceramic restorations have made it possible to overcome the disadvantages of metal [5]. Pre-prosthetic corono-radicular reconstructions should also be metal free as much as possible.

Now a days, Adhesive Corono-Radicular Reconstructions (CRR) using a combination of fiber reinforced post (FRP) and resin composites is the reference[3].

The purpose of this article is to illustrate, through a clinical case, the free metal restoration of a decayed maxillary central incisor while insisting on the contribution of this choice.

\section{Case Report}

A 24-year-old female patient, in good general condition, consulted the department of prosthodontics for the restoration of the Right Maxillary Central Incisor. During the interview, the patient stated that she suffered trauma to the central incisor. She received endodontic treatment followed by a provisional prosthesis dating from 4 months. The endobuccal examination revealed sufficient hygiene with the absence of any gingival inflammation. Except the tooth 11, all teeth were intact and had low translucency. Examination of the period ontium revealed a fine biotype. The provisional prosthesis had a reduced mesiodistal width compared to the tooth 21 and did not participate in the anterior guidance (Fig. 1).

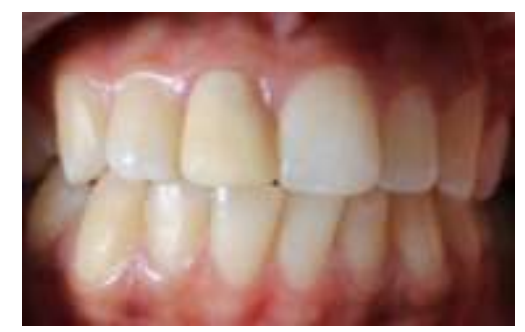

Figure 1: Endobuccal view in Occlusion. Note the disharmony of the provisional prosthesis

The provisional prosthesis was deposited, the tooth have been prepared peripherally, and also at the root level. We noted a supra gingival situation of at least $2 \mathrm{~mm}$ of residual tooth tissue. (Fig. 2).

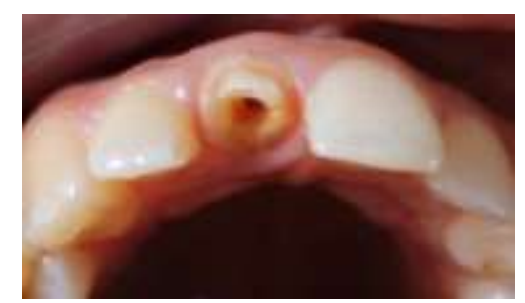

Figure 2 : Occlusal view of the dilapidated central incisor

Residual dental tissues were discolored. The coronal height of the adjacent central was normal. Overbite and over jet 


\section{International Journal of Science and Research (IJSR) \\ ISSN (Online): 2319-7064 \\ Index Copernicus Value (2016): 79.57 | Impact Factor (2015): 6.391}

was normal. The tooth 41 was malpositioned: with a prominent incisal edge on the distal side (Fig.3).

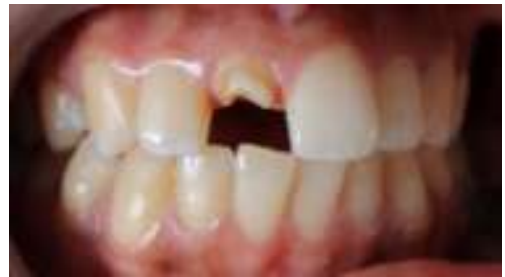

Figure 3 : Buccal view

The cleaning of the prepared canal was followed by the installation of a radio paque post, then a Periapical radiograph was performed.

We found an endodontic safety of about 4 mmwith a healthy periapical environment. The root was well anchored in the alveolar bone. (Fig.4).

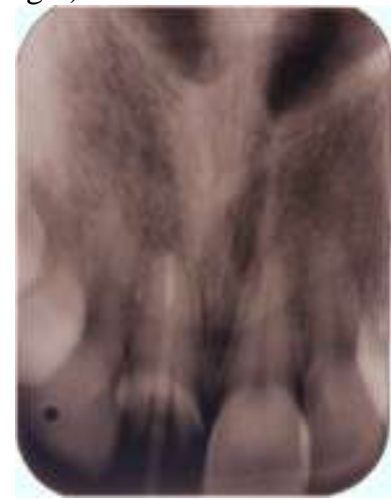

Figure 4: Periapical radiograph

The prosthetic decision was: anall ceramic crown on an adhesive Corono-Radicular Reconstruction (CRR). We opted for a ceramic crown with a zirconia-based framework and for the Indirect CAD-CAM technology (Computer Aided Design-Computer Aided Manufacturing).

Our preprosthetic treatment began with the rectification of the peripheral preparation. Then, a direct CRR using a glass fiber post and resin was performed (Fig.5).

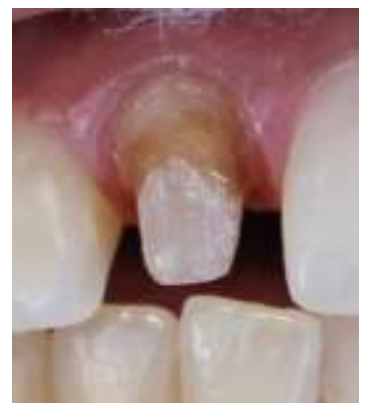

Figure 5 : the abutment was reconstituted with Adhesive CRR reinforced by fiber post.

A new provisional prosthesis was made and sealed with a temporary free-eugenolcement. A non-compressive global impression was achieved and sent to the laboratory to produce the working cast (Fig.6)

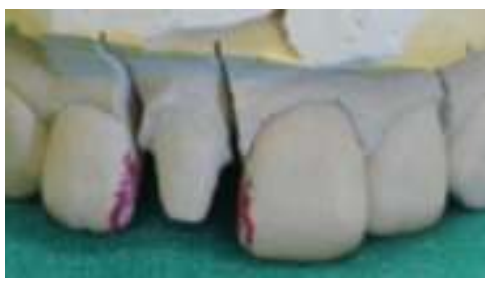

Figure 6 : Working cast and the die was performed

After making it in the laboratory, the zirconia framework was tested in the mouth: the insertion, the cervical adaptation and the space reserved for the cosmetic ceramics were checked (Fig.7).

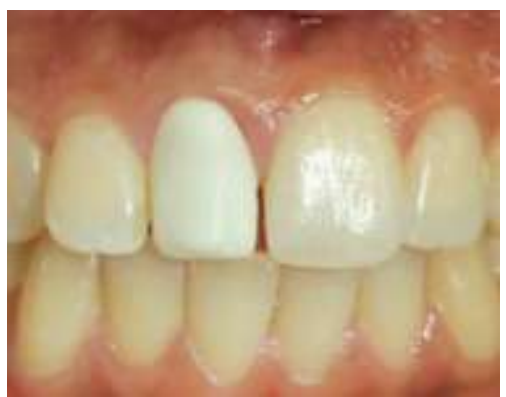

Figure 7 : Buccal view of the zirconia framework

Color was determined at the level of the adjacent central incisor. A try-in appointment in the biscuit bake was achieved. It consisted of an adjustment of the occlusion both statically and dynamically. We performed an enameloplasty on the tooth 41 in order to reach a functional anterior guidance.

Examination of the buccal surface of the adjacent central incisor was crucial. All details of morphology and surface were noted and then transmitted to the laboratory to reproduce the mat the level of the prosthetic buccal face (Fig.8).

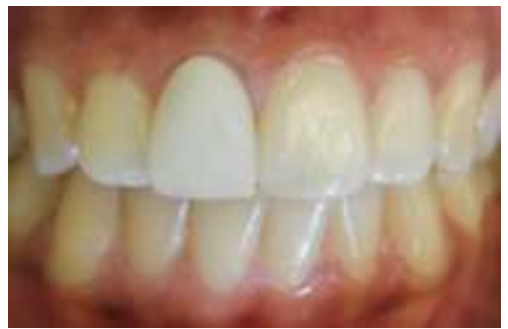

Figure 8 : Buccal view of restoration in the bisque bake, before glazing

Which allowed to optimize the esthetic result after corrections and glazing in the laboratory (Fig.9).

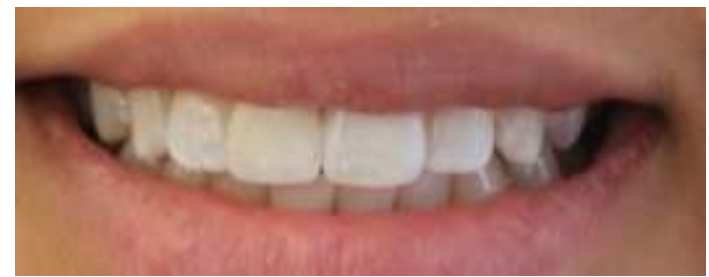

Figure 9: Smile of the patient after cementing the final prosthesis

Volume 6 Issue 12, December 2017

www.ijsr.net

Licensed Under Creative Commons Attribution CC BY 


\section{International Journal of Science and Research (IJSR) \\ ISSN (Online): 2319-7064 \\ Index Copernicus Value (2016): 79.57 | Impact Factor (2015): 6.391}

The optimization of the esthetic result was highlighted by a transillumination test confirming the good circulation of light at the level of restored tooth (Figure 10).

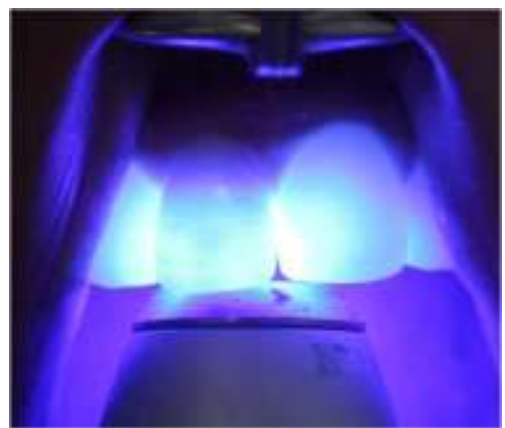

Figure 10: Transillumination test

\section{Discussion}

Metal-ceramic restoration were the standard prostheses for bothesthetic and mechanical requirements. The restoration of a maxillary central incisoris a delicate task especially with athin type periodontium. The indication of a metal-ceramic crown in this clinical case would not have led to a satisfactory esthetic result. In presence of a thin gingiva, the intrasulcularly positionnig of the restoration margins will not prevent the unsightly greyish appearanceat the level of the cervical area. Besides that, the metal framework blocks light which gives the tooth a rather opaque appearance that does not conform to the natural appearance. In the case of dilapidated teeth, the use of metal corono-radicular reconstructions will also accentuate this light blocking effect. In our case, we have discarded metal alloys when choosing reconstitution and restoration materials. Which made it possible to avoid all the aforementioned drawbacks. Several ceramic frameworks are marketed, zirconia-based frameworks are promising in this field. In our case, the use of zirconia, semi-opaque, allowed to mask the dyschromia of the theunderlying dental structures[5,6]. Our patient had low translucent teeth which further favored this indication. The treatment of dilapidated endodontically treated teeth requires in several cases the realization of pre-prosthetic coronoradicular reconstructions. From the esthetic point of view, metal post and core do not have any disadvantages under metal-ceramic restorations. But with the appearance of all ceramic restorations these present an handicap. It is now accepted that bonded fiber-based CRR is an excellent alternative to CRR with metal post. They are part of an adhesive dentistry that is less invasive and more respectful of residual dental structures. These bonded CRR have many advantages. They significantly improve the esthetics thanks to a refractive index similar to dental tissue. They recreate the chromatic heart of the tooth. This allows achieving allceramicprosthetic with a good circulation of light. From a mechanical point of view, these CRR are characterized by a modulus of elasticity similar to dentin. They allow the consolidation of residual dental structures and the reconstitution of a more homogeneous structure. The result being a better distribution of the functional loads.
The restoration of the dilapidated maxillary central incisoris a frequent task in our practice. The systematic use of metalceramic crowns and in lay cores should stop. In several cases, the disadvantages of metal alloys can be avoided by an all-ceramic crown and the reconstruction of the tooth abutment with a bonded CRR [7].

For the optimization of the result, particular care must be given to the morphology of the central incisor, its relationship with adjacent teeth and its surface condition.

\section{References}

[1] Etienne O, Hajtò J. Lesmatériaux céramique en « prothèse sans métal ». Cah Prothèse 2011;155:5-13.

[2] S. Monchanin, S. Viennot, Y. Allard, G. Malquarti. Réalisation au laboratoire de prothèses fixées céramométalliques. Encycl Med Chir (Editions Scientifiques et Médicales, Elsevier SAS, Paris, tous droits réservés), Odontologie, 23-380-C-10,2008.

[3] S.-A. Koubi, J.-L. Brouillet, A. Faucher, G. Koubi, H. Tassery.Nouveaux concepts en dentisterie esthétique.Encycl Med Chir (EditionsScientifiques et Médicales, Elsevier SAS, Paris, tous droits réservés), Odontologie, , 23-250-A-12,2008.

[4] J.-J. Guyonnet, R. Esclassan, G. Gregoire Électrogalvanisme buccal

[5] Encycl Med Chir (EditionsScientifiques et Médicales, Elsevier SAS, Paris, tous droits réservés), Odontologie,23-063-D-10,2008.

[6] Conrad HJ, Seong WJ, Pesun IJ. Current ceramic materials and systems with clinical recommandations: Asystematic review. J Prosthet Dent 2007;98:389-404.

[7] P.Margossian, G.Laborde.Propriétés optiques des systèmes céramo-céramiques : implications cliniques. Clinic $2007 ; 28$.

[8] P Margossian, G Laborde. Restaurations céramocéramiques. Encycl Med Chir (Editions Scientifiques et Médicales, Elsevier SAS, Paris, tous droits réservés), Odontologie, 23-272-C-15, 2007

\section{Conclusion}

Volume 6 Issue 12, December 2017

www.ijsr.net

Licensed Under Creative Commons Attribution CC BY 